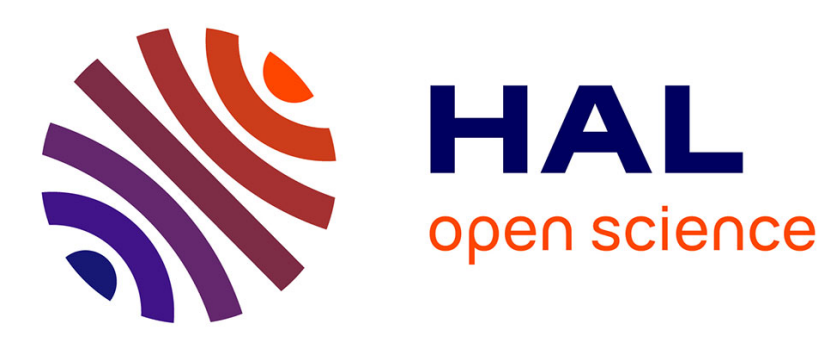

\title{
Artichoke ( L.) fibres as potential reinforcement of composite structures
}

V. Fiore, A. Valenza, G. Di Bella

\section{To cite this version:}

V. Fiore, A. Valenza, G. Di Bella. Artichoke ( L.) fibres as potential reinforcement of composite structures. Composites Science and Technology, 2011, 71 (8), pp.1138. 10.1016/j.compscitech.2011.04.003 . hal-00753182

\section{HAL Id: hal-00753182 https://hal.science/hal-00753182}

Submitted on 18 Nov 2012

HAL is a multi-disciplinary open access archive for the deposit and dissemination of scientific research documents, whether they are published or not. The documents may come from teaching and research institutions in France or abroad, or from public or private research centers.
L'archive ouverte pluridisciplinaire HAL, est destinée au dépôt et à la diffusion de documents scientifiques de niveau recherche, publiés ou non, émanant des établissements d'enseignement et de recherche français ou étrangers, des laboratoires publics ou privés. 


\section{Accepted Manuscript}

Artichoke (Cynara cardunculus L.) fibres as potential reinforcement of composite structures

V. Fiore, A. Valenza, G. Di Bella

PII:

S0266-3538(11)00135-7

DOI:

10.1016/j.compscitech.2011.04.003

Reference:

CSTE 4963

To appear in:

Composites Science and Technology

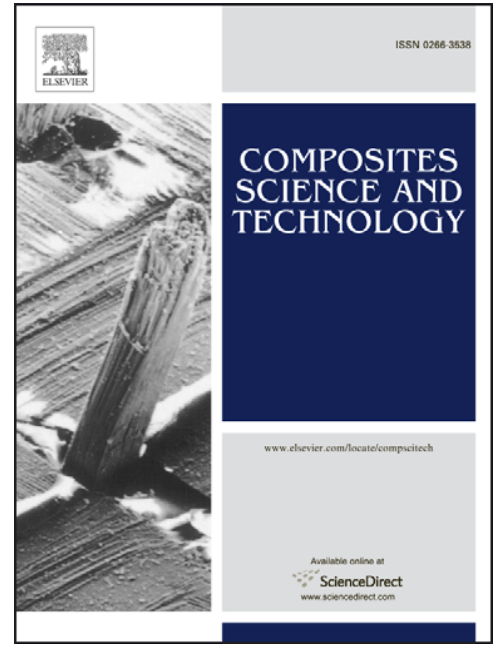

Received Date: $\quad 22$ December 2010

Revised Date: $\quad 4$ April 2011

Accepted Date: $\quad 7$ April 2011

Please cite this article as: Fiore, V., Valenza, A., Di Bella, G., Artichoke (Cynara cardunculus L.) fibres as potential reinforcement of composite structures, Composites Science and Technology (2011), doi: 10.1016/j.compscitech. 2011.04.003

This is a PDF file of an unedited manuscript that has been accepted for publication. As a service to our customers we are providing this early version of the manuscript. The manuscript will undergo copyediting, typesetting, and review of the resulting proof before it is published in its final form. Please note that during the production process errors may be discovered which could affect the content, and all legal disclaimers that apply to the journal pertain. 


\title{
Artichoke (Cynara cardunculus L.) fibres as potential reinforcement of composite structures
}

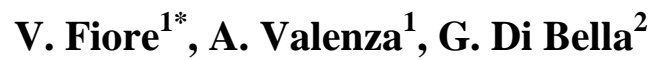 \\ ${ }^{1}$ Department of "Ingegneria Civile, Ambientale e Aerospaziale", \\ University of Palermo, \\ 90128 Palermo, Italy \\ Phone: 003909123863708 \\ Fax: 00390917025020 \\ E-mail: vincenzo.fiore@unipa.it; valenza@unipa.it \\ ${ }^{2}$ CNR ITAE \\ Via Salita Santa Lucia sopra Contesse 5, 98126 Messina, Italy \\ E-mail: guido.dibella@itae.cnr.it
}

* Corresponding author 


\section{Abstract}

The aim of this paper is to examine the use of artichoke fibres as potential reinforcement in polymer composites. The fibres are extracted from the stem of artichoke plant, which grows in Southern Sicily. In order to use these lignocellulosic fibres as potential reinforcement in polymer composites, it is fundamental to investigate their microstructure, chemical composition and mechanical properties.

Therefore, the morphology of artichoke fibres was investigated through electron microscopy, the thermal behaviour through thermogravimetric analysis and the real density through a helium pycnometer. The chemical composition of the natural fibres in terms of cellulose, lignin, and ash contents was determinated by using standard test methods.

Finally, the mechanical characterization was carried out through single fibre tensile tests, analysing the results through statistical analysis.

Keywords: Lignocellulosic fibres; B. Mechanical properties, D. Infrared (IR) spectroscopy; D. Thermogravimetric analysis (TGA); D. Scanning electron microscopy (SEM) 


\section{Introduction}

The use of natural fibres as reinforcement of composite materials, instead of the synthetic ones (i.e. Glass, carbon or Kevlar fibres), has received growing attention in the last few years thanks to their specific properties, their price, their advantages for health and their recyclability [1]. There is a wide variety of different natural fibres which can be applied as reinforcements. The most widely used are flax, hemp, jute, kenaf and sisal, because of their properties and availability. Some recent scientific works advance the feasibility to use other natural fibres, such like okra [2] and isora [3], as reinforcement for composite materials.

The aim of this study is to identify microstructure, chemical composition and mechanical properties of a new kind of fibres, extracted from the stem of a plant of the asteraceae family (Cynara cardunculus L. var. scolymus L.), to make it possible to use them as potential reinforcement in polymer composites.

Globe artichoke is a plant whose capitula, commonly referred to as 'heads' or 'buds', are consumed worldwide as a fresh, canned or frozen vegetable. The major use of globe artichoke is for human food, but other potential uses are as a source of fresh biomass, as forage for livestock, as a feedstock for the preparation of alcoholic beverages, and as a source of inulin. Furthermore, many references exist in pharmacopoeia describing its health-promoting properties. Italy is the leading producer of globe artichoke, followed by Spain and France. In Italy (mainly Apulia, Sicily and Sardinia), artichoke production is an important activity for economic stability and social development and, thanks to its long growth cycle, its cultivation provides employment opportunities almost the whole year round [4].

These fibres have been chosen for several reasons: 
1. the cultivation of artichoke is a local activity. This is important in the development of a sustainable material because allows to reduce not only the costs but also the environmental impacts (i.e. costs and impacts of transportations);

2. as shown previously, the artichoke is cultivated for many applications: mainly as food. For this, its cultivation avoids the "cash crop" (i.e. crop which is grown for profit. The term is used to differentiate from subsistence crops, which are those grown as food);

3. in 2007, the Sicily has produced about 1.5 billion of "heads. Consequently the potential market of this crop is huge (i.e. about $€ 173$ million), due both to its great use in traditional cuisine and to its health value;

4. the fibres are extracted by the stems that represent a waste product. For the large quantities, their disposal is difficult;

The idea of the Authors is to recover these stems in order to extract the fibres verifying the possibility to use them as reinforcement of composite structure.

\section{Materials and Methods}

Artichoke plant has been collected in a plantation of in the area of Niscemi (Sicily). They belonged to the varietal type 'Violetto di Sicilia', one of the seven Sicilian kinds of globe artichoke identified.

After collecting the fresh plant, the stem was removed and kept under water to allow microbial degradation for 25 days in order to allow fibre extraction. The stems were then washed with deionised water, dried in open air and kept in moisture-proof container (Figure 1) to isolate the fibres (with a length between $100 \mathrm{~mm}$ and $160 \mathrm{~mm}$ ). 
Like the other natural fibres, those extracted from the stem of the artichoke plant have a complex structure, consisting principally of cellulose, hemicellulose, lignin, pectin and other compounds. Each fibre consists of helically wound microfibrils of cellulose, bounded together by an amorphous lignin matrix; the hemicellulose acts as a compatibilizer between cellulose w lignin [5] while pectin is also a bonding agent.

The real density of artichoke fibres was measured using gas intrusion under helium gas flow with a Pycnomatic ATC Thermo Electron Corporation equipment pycnometer. Five measurements were conducted at $20^{\circ} \mathrm{C}$.

The cellulose content of artichoke fibres was calculated by means of the density method suggested by Mwaikambo and Ansell [6]. This method allows to determine the cellulose content by measuring the real (with the technique of helium pycnometry) and apparent density (with the Archimedes method using benzene as a solvent) of the artichoke fibres.

Thermogravimetric analysis (TGA) was carried out to define the thermal stability of artichoke fibres by using a thermobalance TG/DTA Perkin Elmer 6000. Particularly, samples of weights between 2 and $5 \mathrm{mg}$ were placed in a alumina pan and heated from 30 to $700{ }^{\circ} \mathrm{C}$ at a heating rate of $10{ }^{\circ} \mathrm{C} / \mathrm{min}$ in air atmosphere.

The microstructure and morphology of the fibre were investigated by scanning electron microscopy (SEM) using a FEI QUANTA 200 F. Before analysis, each fibre was cut to a height of $10 \mathrm{~mm}$, coated with gold and rubbed upon a $25 \mathrm{~mm}$ diameter aluminum disc. Fourier transform infrared spectrometry (FTIR) was carried out on artichoke fibres to analyse the chemical structure of their components. IR spectrum of the fibres was recorded at the resolutions of $2 \mathrm{~cm}^{-1}$ using a Perkin Elmer spectrometer in the frequency range $4000-500 \mathrm{~cm}^{-1}$, operating in attenuated total reflectance (ATR) mode. 
Thirty fibres were mechanically tested in tension, according to ASTM standards [7], using an UTM by Zwick-Roell, equipped with a load cell of $200 \mathrm{~N}$, at a constant strain rate of $1 \mathrm{~mm} / \mathrm{min}$ and gage length of $10 \mathrm{~mm}$. The results were analysed statistically using a commercial software (i.e. Minitab) as suggested in the literature about the mechanical tests of natural fibres.

\section{Results and Discussion}

\subsection{Real density and chemical composition}

The real density $\rho_{r}$ of the artichoke fibres, measured using a helium pycnometer, was $1.579 \pm 0.008 \mathrm{~g} / \mathrm{cm}^{3}$.

Benzene with a density of $0.875 \mathrm{~g} / \mathrm{cm}^{3}$ was used as a non polar solvent for the measurement of the bulk density of fibres and an electronic balance was used to weigh fibres. A sample of fibres was first weighted in air and then immersed in benzene solvent and reweighted.

The apparent density $\rho_{\mathrm{a}}$ of the fibres was calculated using the following equation:

$\rho_{a}=\frac{\rho_{s} \cdot W_{f a}}{W_{f a}-W_{f s}}$

Where $\rho_{s}$ density of benzene; $W_{f a}=$ weight of the fibres in air; $W_{f b}=$ weight of the fibres in benzene.

The value obtained was $1.210 \mathrm{~g} / \mathrm{cm}^{3}$

The cellulose content of the artichoke fibres can be calculated using the following equation:

\%cell $=\left[2 \cdot\left(\frac{\rho_{a}}{\rho_{r}}+\frac{\rho_{r}}{\rho_{\text {cell }}}\right)-\frac{\rho_{a}}{\rho_{\text {cell }}}-2\right] 100$

Where $\rho_{\text {cell }}=1.592 \mathrm{~g} / \mathrm{cm}^{3}$ (density of cellulose [8]) 
Substituting the known values of $\rho_{\mathrm{a}}, \rho_{\mathrm{r}}$ and $\rho_{\text {cell }}$, the obtained value of cellulose content in the artichoke fibres is $75.62 \%$. Obviously this one is only an indirect calculation of the cellulose content in artichoke fibres. To determinate precisely the chemical composition of the natural fibres (i.e. the cellulose, lignin, and ash contents) standard test methods were used.

In particular, the cellulose content in the artichoke fibres was determined as the Acid Detergent Fiber (ADF) according to AOAC method 973.18 [9]while lignin and ash contents were determined according to ASTM standards [10] - [11], respectively. Three measures were done for determining each component and the results are reported in Table 1.

\subsection{Thermal analysis}

The thermal stability of artichoke fibres, one of the limiting factors in the use of natural fibres as reinforcement in composite structures [2], [12], was investigated by thermogravimetric analysis. Figure 2 shows the TG and DTG curves of artichoke fibres. The DTG curve of artichoke fibres shows an initial peak between 40 and $100{ }^{\circ} \mathrm{C}$ (loss in weight about $5 \%$ ), due to the vaporization of water in the fibre. After this peak, the curve exhibits four decomposition steps. In particular, thermal degradation of the artichoke fibres starts at $230{ }^{\circ} \mathrm{C}$ (onset degradation temperature) and the first decomposition peak occurs at about $295{ }^{\circ} \mathrm{C}$, due to the thermal depolymerisation of hemicelluloses and pectin and the glycosidic linkages of cellulose (10\% weight loss). The second peak, at about $352{ }^{\circ} \mathrm{C}$, is due the decomposition of cellulose $(60 \%$ weight loss) while the small third and fourth peaks (at $454^{\circ} \mathrm{C}$ and $510{ }^{\circ} \mathrm{C}$ and loss in weight 
equal to $9 \%$ and $3 \%$, respectively) may be attributed to oxidative degradation of the charred residue [13].

The decomposition of lignin, whose structure is a complex composition of aromatic rings with various branches, happens at a very low weight loss rate within the whole temperature range from ambient to temperatures higher to $700{ }^{\circ} \mathrm{C}[2],[14]$.

Thermal analysis shows that the artichoke fibres are stable until around $230{ }^{\circ} \mathrm{C}$, value similar to those of other natural fibres like okra $\left(220^{\circ} \mathrm{C}\right)$, hemp $\left(250{ }^{\circ} \mathrm{C}\right)$, curaua $\left(230^{\circ} \mathrm{C}\right)$, kenaf $\left(219^{\circ} \mathrm{C}\right)$, Jute $\left(205^{\circ} \mathrm{C}\right)[2]$, sisal $\left(230^{\circ} \mathrm{C}\right)[15]$, bagasse $\left(222^{\circ} \mathrm{C}\right)$ and bamboo $\left(214^{\circ} \mathrm{C}\right)[16]$.

\subsection{Surface morphology}

Figure 3 shows the surface morphology of artichoke fibres. Like other natural fibres the surface morphology of the fibre of artichoke consists of several elementary fibres (know as fibrils or fibre-cells) bonded together in the direction of their length of fibres by pectin and other non-cellulosic compounds [2], [17]-[18], to form a bundle of diameter up to $300 \mu \mathrm{m}$.

Figure 3 shows also the presence of some impurities on the surface of the fibres, typical of the raw natural fibres like artichoke one. In order to eliminate these impurities and enhance interface adhesion with polymer matrices, the natural fibres have often treated chemically [19]-[21].

Figure 4 shows the cross section of the artichoke fibres highlighting the structure of fibre-cells, with polygonal shape and a central hole, named lumen [22]. Like other natural fibres, the variability in diameter of fibre-cells and lumen has a great influence on the mechanical properties of artichoke fibres [2]. 


\subsection{Fourier transforms infrared spectroscopy}

Figure 5 shows the ATR-FTIR spectrum of artichoke fibre, in which the most interesting absorbance peaks have been highlighted.

The peak at $3342 \mathrm{~cm}^{-1}$ can be caused by the O-H stretching vibration and hydrogen bond of the hydroxyl groups [14], [23].

The peaks at $2923 \mathrm{~cm}^{-1}$ and $2854 \mathrm{~cm}^{-1}$ are the characteristic band for the $\mathrm{C}-\mathrm{H}$ stretching vibration from $\mathrm{CH}$ and $\mathrm{CH}_{2}$ in cellulose and hemicellulose components [24] while the absorption band centred at $1737 \mathrm{~cm}^{-1}$ can be attributed to the carbonylic group $\mathrm{C}=\mathrm{O}$ stretching vibration of linkage of carboxylic acid in lignin or ester group in hemicellulose [14], [20].

The peak centred at $1594 \mathrm{~cm}^{-1}$ may be explained by the presence of water in the fibres [25] while the little peak at $1506 \mathrm{~cm}^{-1}$ is attributed to $\mathrm{C}=\mathrm{C}$ stretching of aromatic ring of the lignin [2]. The absorbance at $1422 \mathrm{~cm}^{-1}$ is associated to the $\mathrm{CH}_{2}$ symmetric bending present in cellulose [26]. The two peaks observed at $1372 \mathrm{~cm}^{-1}$ and $1318 \mathrm{~cm}^{-1}$ are attributed to the bending vibration of $\mathrm{C}-\mathrm{H}$ and $\mathrm{C}-\mathrm{O}$ groups of the aromatic ring in polysaccharides [27] while the absorbance peak centred at $1245 \mathrm{~cm}^{-1}$ is due to the $\mathrm{C}-\mathrm{O}$ stretching vibration of the acetyl group in lignin [19]

The intense band with two shoulders, centred at $1035 \mathrm{~cm}^{-1}$, can be associated to the $\mathrm{C}-$ O stretching modes of hydroxyl and ether groups in cellulose [24].

The little peak at $892 \mathrm{~cm}^{-1}$ can be attributed to the presence of b-glycosidic linkages between the monosaccharides [2] whilst the absorbance at $598 \mathrm{~cm}^{-1}$ corresponds to the C-OH bending [28].

\subsection{Mechanical characterization}

In Figure 6 a typical stress-strain curve for artichoke fibre is shown. It is clearly visible that the fibres exhibit a brittle behaviour with a sudden load drop when fibre failure 
occurs. However, the results of the tensile test on single filament of small brittle natural fibres are difficult to analyze because of the high scatter observed. This scatter can be mainly related to three factors; i.e. test parameters/conditions, plant characteristics and area measurements [29]. As regards the plant characteristics, the factors affecting the mechanical behaviour are: the source of the plant, its age, the processes of fibre extraction and the presence of defects. These features make it necessary to use statistical approaches to assess the mechanical properties.

Figure 7 and Figure 8 show respectively tensile strength and Young's modulus as a function of diameter for artichoke fibres. Both tensile strength and Young's modulus decrease as diameter increase, like it has been reported for other natural fibres [30]-[35]. These figures highlight the presence of a wide range of diameters in the same bunch of fibres, that is a common drawback for natural fibres. From these figures, a high dispersion of results is also evident. An attempt was made to model the variation of both mechanical properties with diameter size using the Griffith model through the following empirical expression [34]-[36]:

$$
E_{f}\left(d_{f}\right)=A+\frac{B}{d_{f}}
$$

where $E_{f}\left(d_{f}\right)$ represents the measured property, $A$ and $B$ are parameters and $d_{f}$ is the fibre diameter. The black lines in the Figures represent the Griffith model, while the model parameters (i.e. A and B) are reported in Table 2. It is clear that a two-parameter model is not able to accurately interpolate experimental results characterized by high scatter.

Artichoke fibres exhibited variability in tensile strength and Young's modulus, which is quite common for natural fibres. Therefore, the values obtained by mechanical characterization were statistically analyzed using a two-parameter Weibull distribution. 
This method has been often used to analyze mechanical and physical data for natural fibres [31],[33],[34],[38].

Figure 9 and Figure 10 show the Weibull distributions for tensile strength and Young's modulus of artichoke fibres. It can be seen that a two-parameter Weibull distribution provides a reasonable approximation of the experimental data for both mechanical properties. The Weibull shape and scale parameters (that are characteristic values of the distribution) for both of the investigated property are reported in Table 2 and in the same figures, where the characteristic statistical parameters are indicated as well. In particular, the shape parameter indicates the varibability of the data. A shape of 3 approximates a normal curve. A shape between 2 and 4 is still fairly normal. A low value for shape, say 1.25, gives a right-skewed curve. A high value for shape, say 10, gives a left-skewed curve. Moreover, higher shape parameter is equivalent to lower coefficient of variation in a normal distribution. The scale parameter, or characteristic life, is the 63.2 percentile of the data. The scale defines the position of the Weibull curve. The results show that mechanical properties of artichoke fibres are comparable to those of other natural fibres, as shown in Table 3 [39], that are currently investigated as potential reinforcement in polymer matrix composites. This confirms that there is scope for further investigation of these fibres as reinforcement in structural composites.

\section{Conclusions}

Italy is the world leading producer of globe artichoke and, particularly in Sicily, this plant is widespread, making its production an important activity for economic stability. While the heads of artichokes are disposable in a wide range of activities, the stems are in most cases the waste products. 
In this paper we have examined the fibres extracted from the stems of the artichoke plant in order to evaluate the possibility of using them as reinforcement in polymer matrix composites.

Therefore, the fibres obtained were characterized by electron microscopy and FTIR. Their thermal degradation behaviour was fully investigated through TGA and DTG curves. Mechanical properties of these fibres were assessed by single fibre tensile tests and the results were analyzed through a Weibull distribution. The real density of the fibres was evaluated using a helium pycnometer.

The experimental results are comparable to those of other common natural fibres, confirming that these fibres represent a valid alternative to synthetic ones (i.e. glass) as reinforcement in composite structures.

The use of these fibres in Sicily, where the artichoke production is huge, can produce important benefits in terms of new jobs (i.e. green jobs) in a region with high unemployment. Moreover, the new composite structures, that will be investigated, can be used by the shipyards that work in the region. In the last years, the interest toward the construction of green ships (i.e. in terms of materials or propulsion) is particularly increased. In conclusion, the stems can be recovered in order to extract the fibres creating an industrial chain, highly localised (i.e. from the cultivated fields to the shipyards), with an advantage in terms of environmental and social impacts, and costs.

The future goal of this research work is to combine this kind of fibres with thermoset resins obtained from natural sources in order both to analyse the fibre/matrix adhesion, evaluating the necessity of a chemical pre-treatment of the fibres, and to study the mechanical properties of this new kind of composites. 


\section{References}

[1] Bos HL. The potential of flax fibres as reinforcement for composite materials. PhD Thesis, Eindhoven University of Technology: University Press Facilities; 2004.

[2] De Rosa IM, Kenny JM, Puglia D, Santulli C, Sarasini F. Morphological, thermal and mechanical characterization of okra (Abelmoschus esculentus) fibres as potential reinforcement in polymer composites. Compos Sci Technol 2010; 70: $116-122$.

[3] Mathew L, Joseph KU, Joseph R. Isora fibre: Morphology, chemical composition, surface modification, physical, mechanical and thermal properties A potential natural reinforcement. J Nat Fibres 2006; 3: 13-27.

[4] Portis E, Mauromicale G, Barchi L, Mauro R, Lanteri S. Population structure and genetic variation in autochthonous globe artichoke germplasm from Sicily Island. Plant Sci 2005; 168: 1591-1598.

[5] Kalia S, Kaith BS, Kaur I. Pretreatments of natural fibers and their application as reinforcing material in polymer composites-a review. Polym Eng Sci 2009; 49: $1253-1272$.

[6] Mwaikambo LY, Ansell MP. The determination of porosity and cellulose content of plant fibres by density methods. J Mater Sci Lett 2001; 20: 20952096.

[7] ASTM D 3379 - 75 (1975 Reapproved 1989). Standard test method for tensile strength and Young's modulus for high-modulus single-filament materials. ASTM International, West Conshohocken, PA. 
[8] Meredith R. The Mechanical Properties of Textile Fibers, North-Holland Publishing Company, Amsterdam, 1956.

[9] AOAC Method 973.18 (1990). Fiber (Acid Detergent) and lignin in animal feeds. Official method of analysis of the association of official analytical chemists, 15th ed., vol. 82. Arlington, VA, USA.

[10] ASTM D 1106 - 96 (1996 Reapproved 2001). Standard test method for acidinsoluble lignin in wood. ASTM International, West Conshohocken, PA, USA.

[11] ASTM E 1755 - 01 (2007). Standard test method for ash in biomass. ASTM International, West Conshohocken, PA, USA.

[12] Gassan J, Bledzki A. Thermal degradation of flax and jute fibres. J Appl Polym Sci 2001; 82: 1417 - 1422.

[13] Ouajai S, Shanks RA. Composition, structure and thermal degradation of hemp cellulose after chemical treatments. Polym Degrad Stab 2005; 89: 327 335.

[14] Yang H, Yan R, Chen H, Lee DH, Zheng C. Characteristics of hemicellulose, cellulose and lignin pyrolysis. Fuel 2007; 86: 1781 - 1788.

[15] Albano C, Gonzalez J, Ichazo M, Kaiser D. Thermal stability of blends of polyolefins and sisal fibre. Polym Degrad Stab 1999; 66: 179 - 190

[16] Yao F, Wu Q, Lei Y, Guo W, Xu Y. Thermal decomposition kinetics of natural fibres: Activation energy with dynamic thermogravimetric analysis. Polym Degrad Stab 2008; 93: 90 - 98.

[17] Arifuzzaman Khan GM, Shaheruzzaman M, Rahman MH, Abdur Razzaque SM., Islam MS, Alam MdS. Surface modification of okra bast fibre and its physico-chemical characteristics. Fibres Polym 2009; 10: 65 - 70. 
[18] Nam S, Netravali AN. Green Composites. I. Physical Properties of Ramie Fibres for Environment-friendly Green Composites. Fibres Polym 2006; 7: 372 379.

[19] Liu W, Mohanty K, Drzal LT, Askel P, Misra M. Effects of alkali treatment on the structure, morphology of native grass fibres as reinforcements for polymer matrix composites. J Mater Sci 2004; 39: 1051 - 1054.

[20] Alawar A, Hamed AM, Al-Kaabi K. Characterization of treated date palm tree fibre as composite reinforcement. Composites: Part B 2009; 40: 601 - 606.

[21] Mohanty AK, Misra M, Drzal LT. Surface modifications of natural fibres and performance of the resulting biocomposites: An overview. Compos Interfaces $2001 ; 8: 313-343$.

[22] Silva F.d.A, Chawla N, Toledo Filho RD. Tensile behavior of high performance natural (sisal) fibres. Compos Sci Technol 2008; 68: 3438 - 3443.

[23] Meenakshi P, Noorjahan SE, Rajini R, Venkateswarlu U, Rose C, Sastry TP. Mechanical and microstructure studies on the modification of CA film by blending with PS. Bull Mater Sci 2002; 25: 25 - 29.

[24] Paiva MC, Ammar I, Campos AR, Cheikh RB, Cunha AM. Alfa fibres: Mechanical, morphological and interfacial characterization. Compos Sci Technol 2007; 67: 1132 - 1138.

[25] Olsson AM, Salmen L. The association of water to cellulose and hemicellulose in paper examined by FTIR spectroscopy. Carbohyd Res 2004; 339: 813 - 818.

[26] Sgriccia N, Hawley MC, Misra M. Characterization of natural fiber surfaces and natural fiber composites. Composites: Part A 2008; 39:1632 - 1637.

[27] Le Troedec M, Sedan D, Peyratout C, Bonnet J, Smith A, Guinebretiere R, Gloaguen V, Krausz P. Influence of various chemical treatments on the 
composition and structure of hemp fibres. Composites: Part A 2008; $39: 514$ 522.

[28] Mwaikambo LY, Ansell MP. Chemical modification of hemp, sisal, jute, and kapok fibers by alkalization. J Appl Polym Sci 2002; 84: 2222 - 2234.

[29] Liu D, Han G, Huang JH, Zhang Y. Composition and structure study of natural Nelumbo nucifera fiber. Carbohydr Polym 2009; 75(1): 39 - 43.

[30] Baley C. Analysis of the flax fibres tensile behaviour and analysis of the tensile stiffness increase. Composites: Part A 2002;33(7):939-948.

[31] Park J-M, Quang ST, Hwang B-S, DeVries KL. Interfacial evaluation of modified Jute and Hemp fibers/polypropylene (PP)-maleic anhydride polypropylene copolymers (PP-MAPP) composites using micromechanical technique and nondestructive acoustic emission. Compos Sci Technol 2006;66(15): $2686-99$.

[32] Shibata M, Takachiyo K-I, Ozawa K, Yosomiya R, Takeishi H. Biodegradable polyester composites reinforced with short abaca fiber. J Appl Polym Sci $2002 ; 85(1): 129-138$.

[33] Andersons J, Sparninš E, Joffe R, Wallström L. Strength distribution of elementary flax fibres. Compos Sci Technol 2005;65(3-4):693-702.

[34] Biagiotti J, Fiori S, Torre L, López-Manchado MA, Kenny JM. Mechanical properties of polypropylene matrix composites reinforced with natural fibers: a statistical approach. Polym Compos 2004;25(1):26 - 36.

[35] Peponi L, Biagiotti J, Torre L, Kenny JM, Mondragòn I. Statistical analysis of the mechanical properties of natural fibers and their composite materials I. Natural fibers. Polym Compos 2008;29(3):313 - 320. 
[36] Griffith AA. The phenomena of rupture and flow in solids. Phil Trans Royal Soc London 1921;A221:163 - 198.

[37] Weibull W. A statistical theory of the strength of materials. Ing Vetenskaps Akad Handl, vol. 151. Stockholm; 1939.

[38] Gañan P, Garbizu S, Llano-Ponte R, Mondragòn I. Surface modification of sisal fibers: effects on the mechanical and thermal properties of their epoxy composites. Polym Compos 2005;26(2):121 - 127.

[39] John KJ, Anandjiwala RD. Recent developments in chemical modification and characterization of natural fiber-reinforced composites. Polym Compos 2008;29(2): $187-207$. 


\section{Figure captions}

Figure 1. Artichoke fibres isolated from the stem

Figure 2. TG and DTG curves of artichoke fibres

Figure 3. Longitudinal view of artichoke fibres

Figure 4. Cross section view of artichoke fibres

Figure 5. FTIR spectrum of artichoke fibres

Figure 6. Stress/Strain curve

Figure 7. Experimental data and Griffith model (line) for tensile strength

Figure 8. Experimental data and Griffith model (line) for Young's modulus

Figure 9. Weibull distribution for tensile strength of artichoke fibres

Figure 10. Weibull distribution for Young's modulus of artichoke fibres

\section{Tables}

Table 1. Chemical composition of artichoke fibres

Table 2. Mechanical parameters for artichoke fibres

Table 3. Mechanical properties of some commonly used natural fibres 


\begin{tabular}{|c|c|}
\hline component & content [\%] \\
\hline cellulose & $75.3 \pm 1.2$ \\
\hline lignin & $4.3 \pm 0.5$ \\
\hline ash & $2.2 \pm 0.05$ \\
\hline
\end{tabular}




\begin{tabular}{|l|l|l|}
\hline & Tensile strength & Young's modulus \\
\hline & Weibull Model & \\
\hline Shape parameter & 3.71 & 4.47 \\
\hline Scale parameter [MPa] & 201 & 11624 \\
\hline & Griffith Model & \\
\hline A $[\mathrm{MPa}]$ & -3.42 & 7350 \\
\hline B $[\mathrm{MPa} \cdot \mathrm{mm}]$ & 38.68 & 685 \\
\hline
\end{tabular}




\begin{tabular}{|c|c|c|}
\hline Fibre & Tensile strength [MPa] & Young's modulus [GPa] \\
\hline sisal & $511-635$ & $9.4-22$ \\
\hline ramie & 560 & 24.5 \\
\hline jute & $393-773$ & 26.5 \\
\hline coir & 175 & $4-6$ \\
\hline bamboo & $140-230$ & $11-17$ \\
\hline cotton & $287-597$ & $5.5-12.6$ \\
\hline flax & $345-1035$ & 27.6 \\
\hline
\end{tabular}


Fig 1 - Artichoke fibres isolated from the stem

ACCEPTED MANUSCRIPT

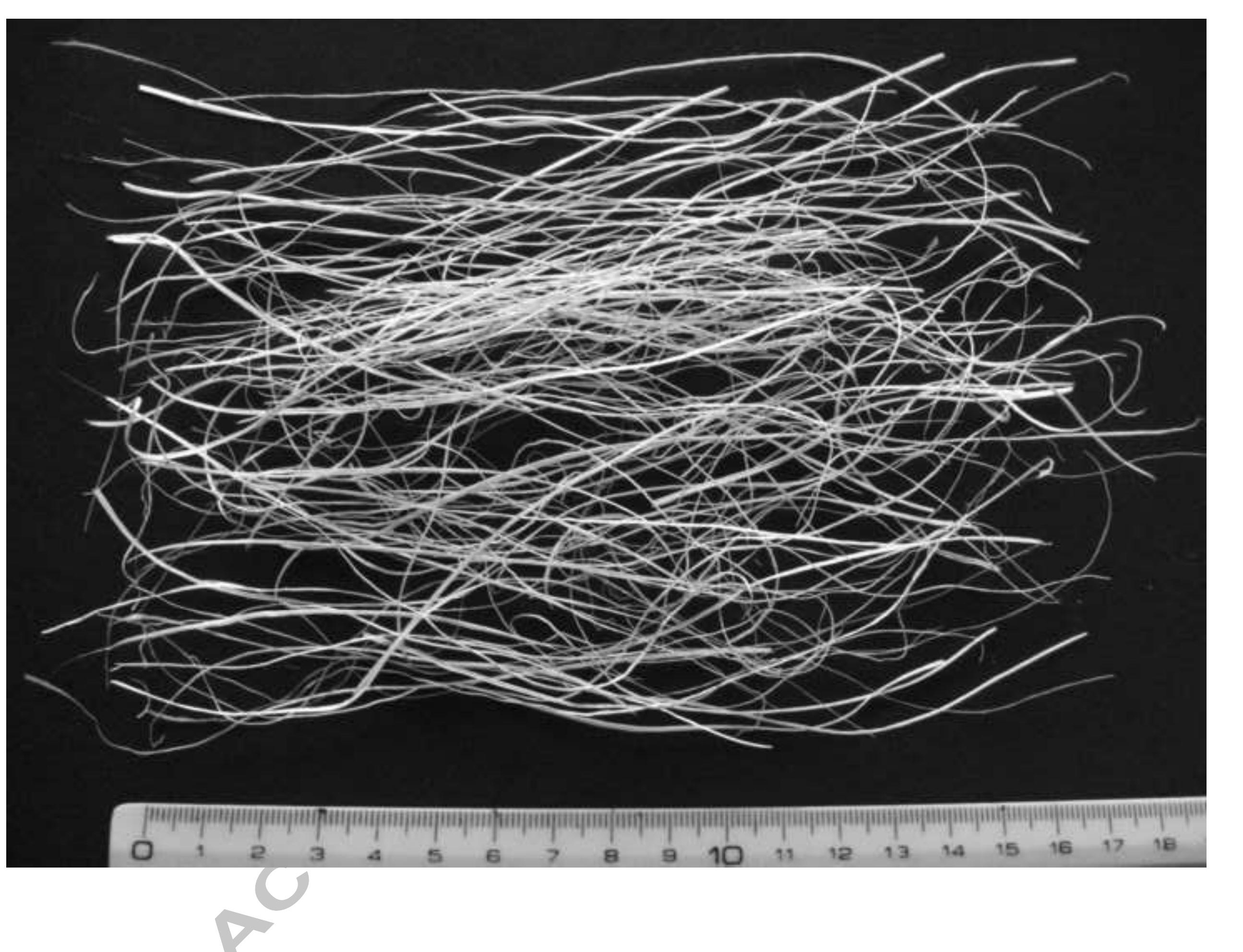




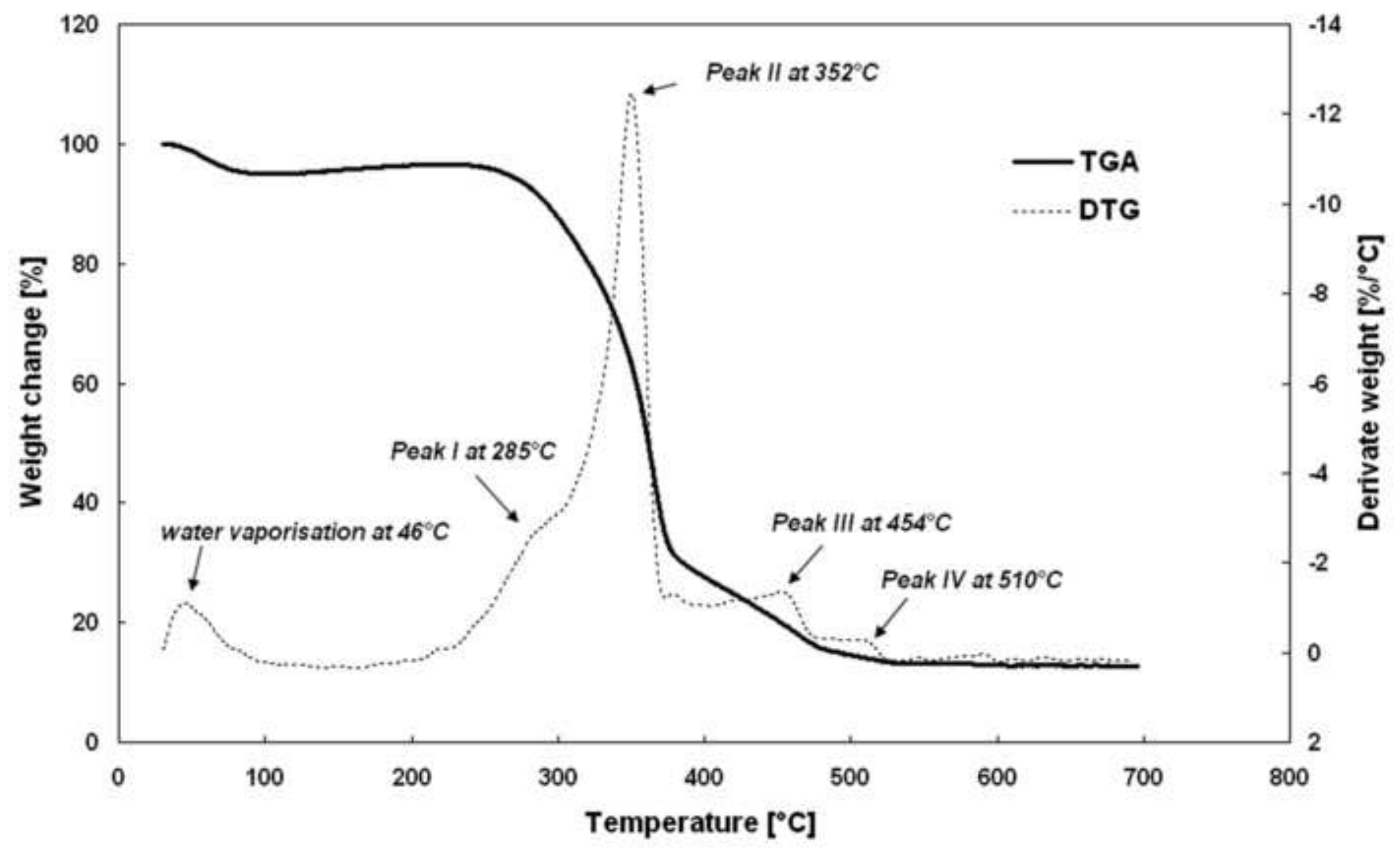




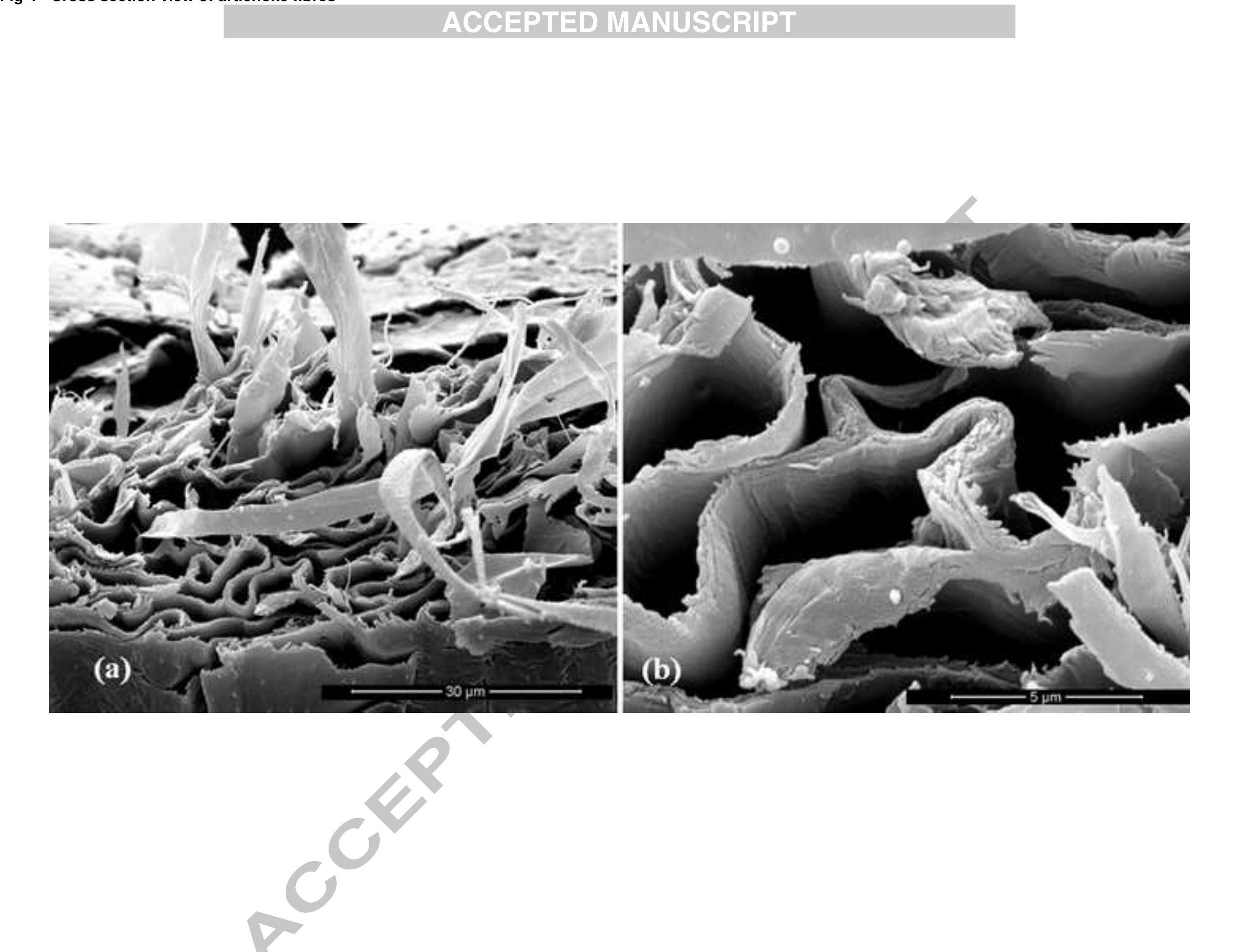

\section{.}
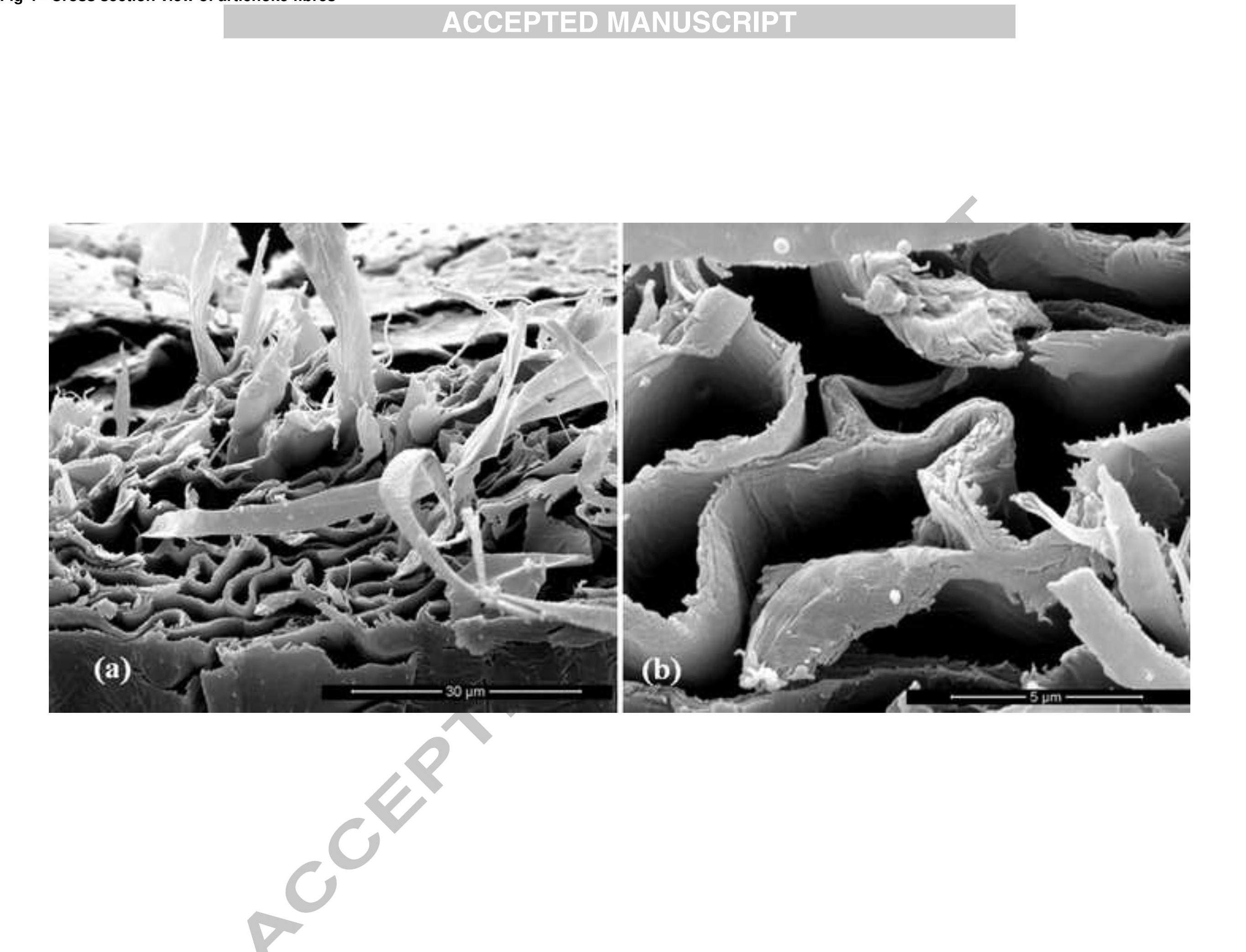


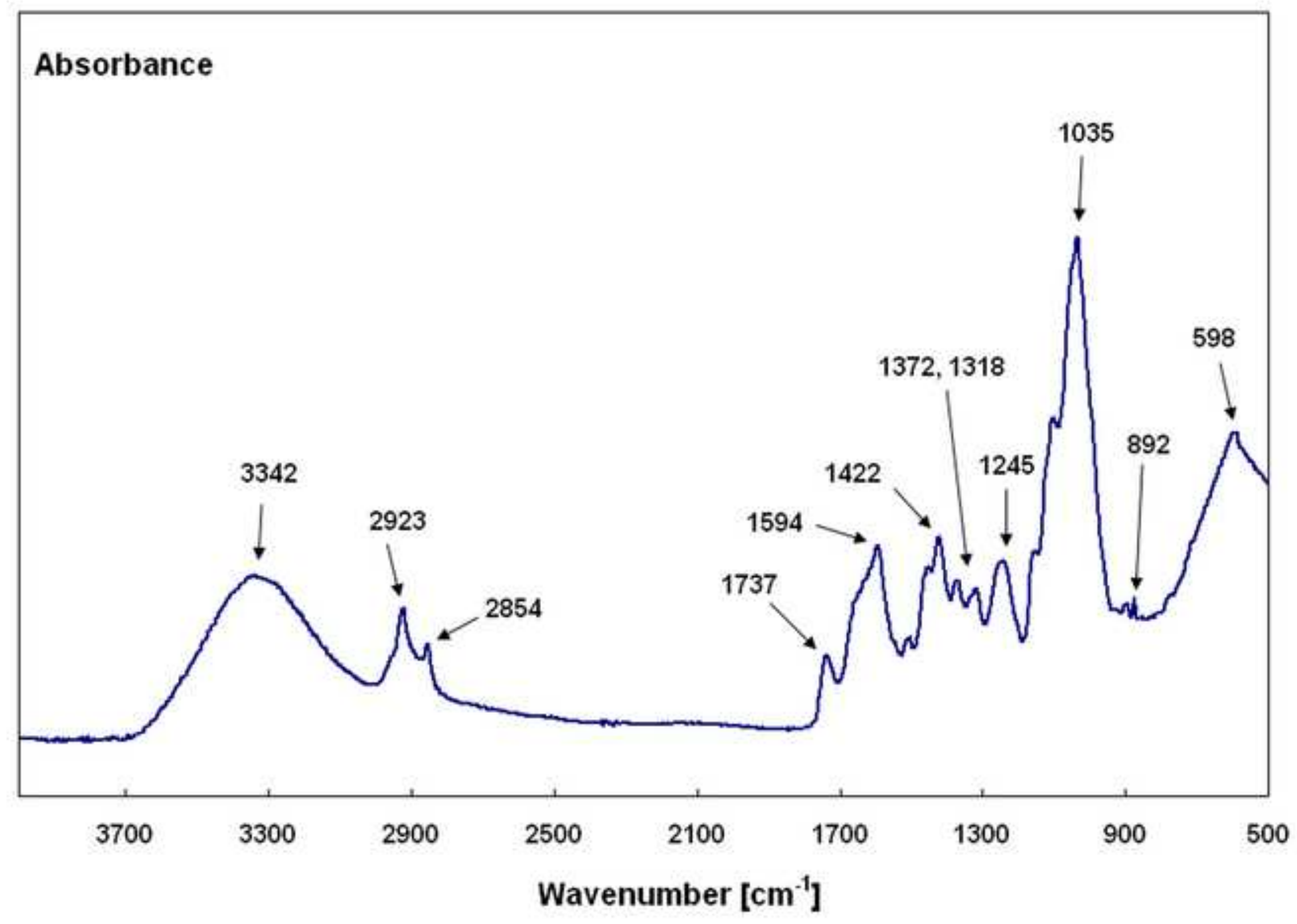


ACCEPTED MANUSCRIPT

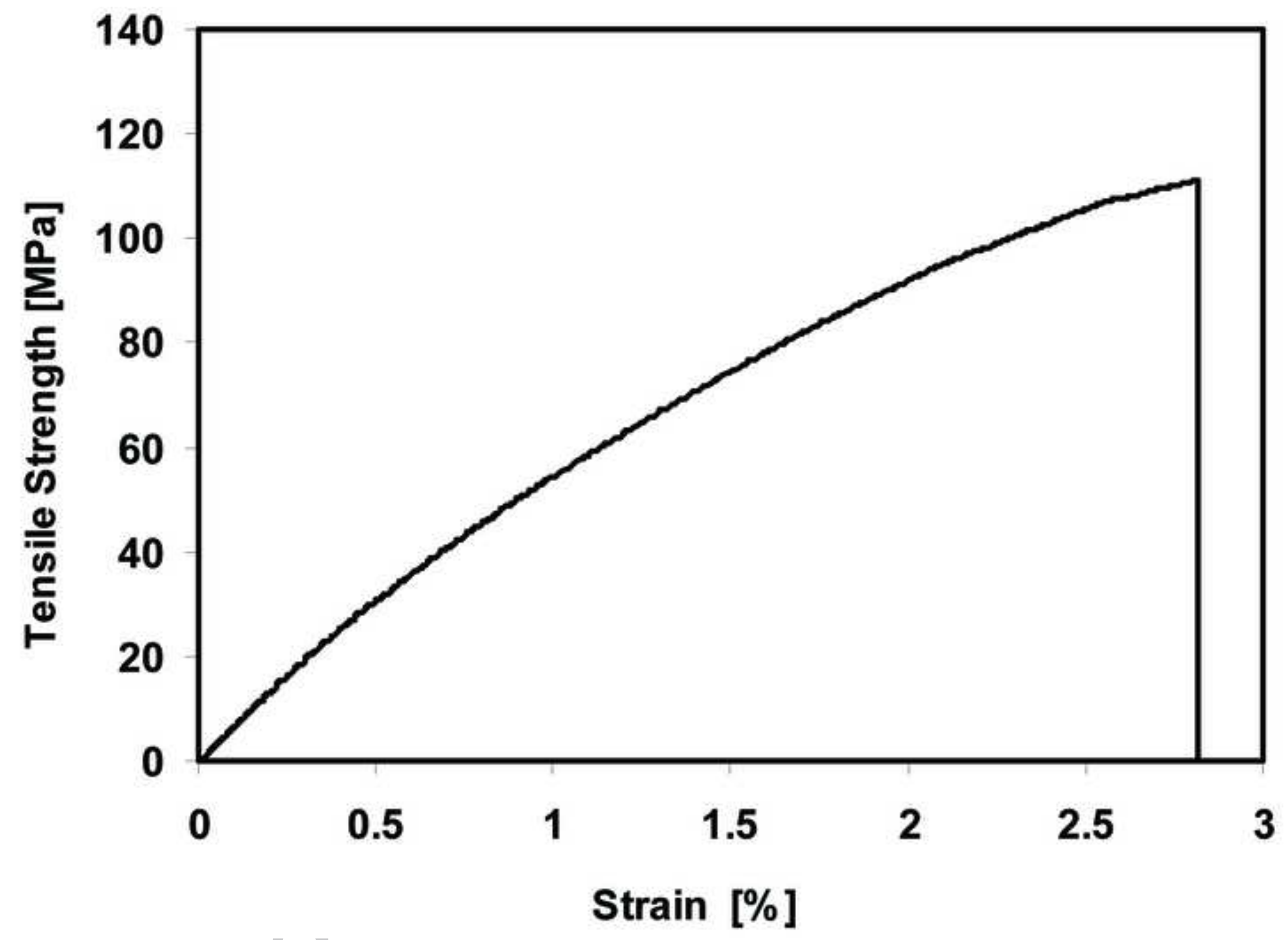




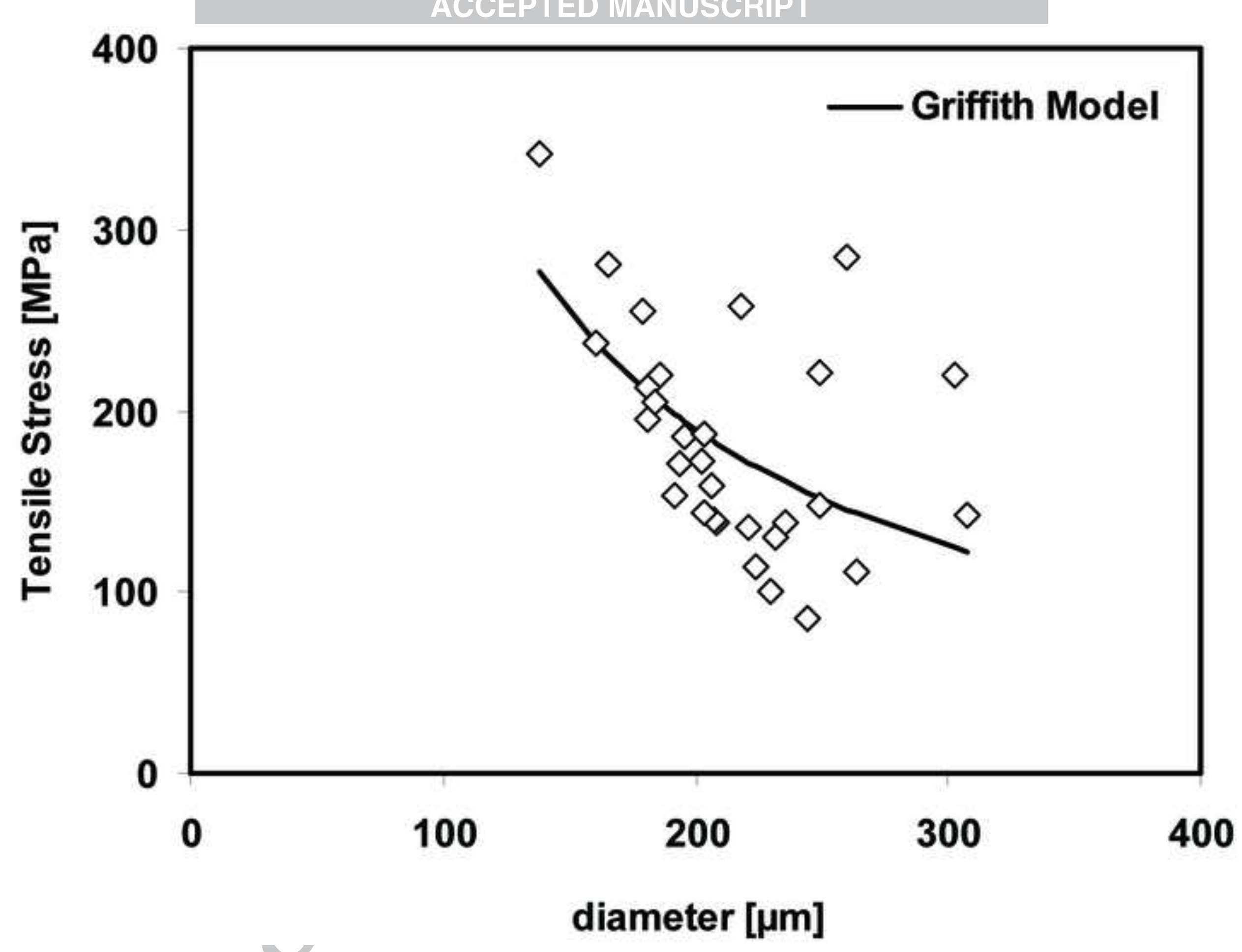




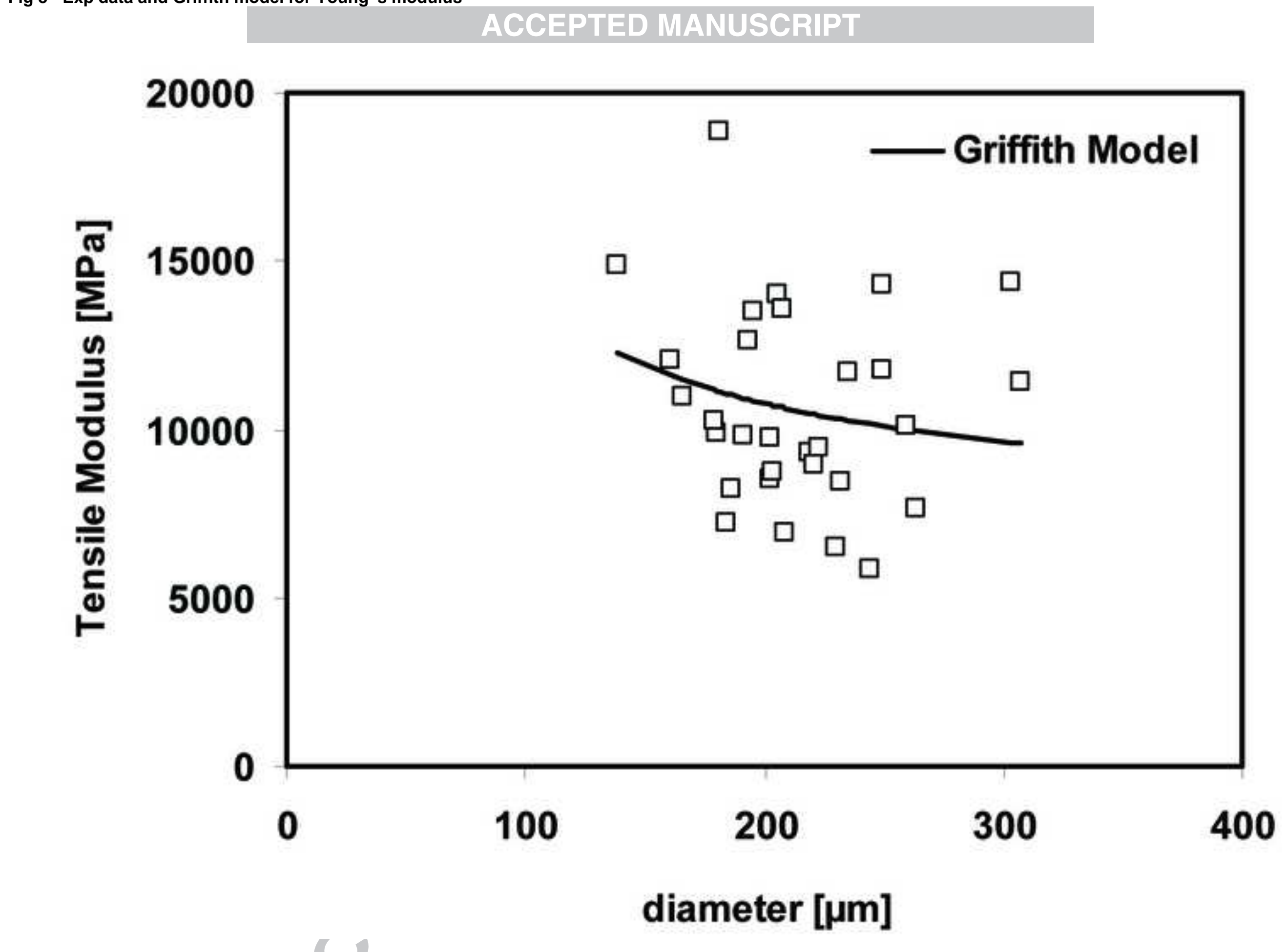

ACCEPTED MANUSCRIPT
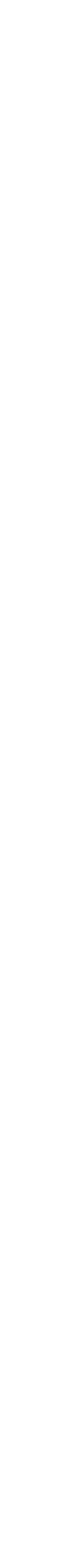

diameter $[\mu \mathrm{m}]$ 


\title{
Probability Plot for Stress [MPa]
}

\author{
Weibull - 95\% CI
}

Complete Data - LSXY Estimates

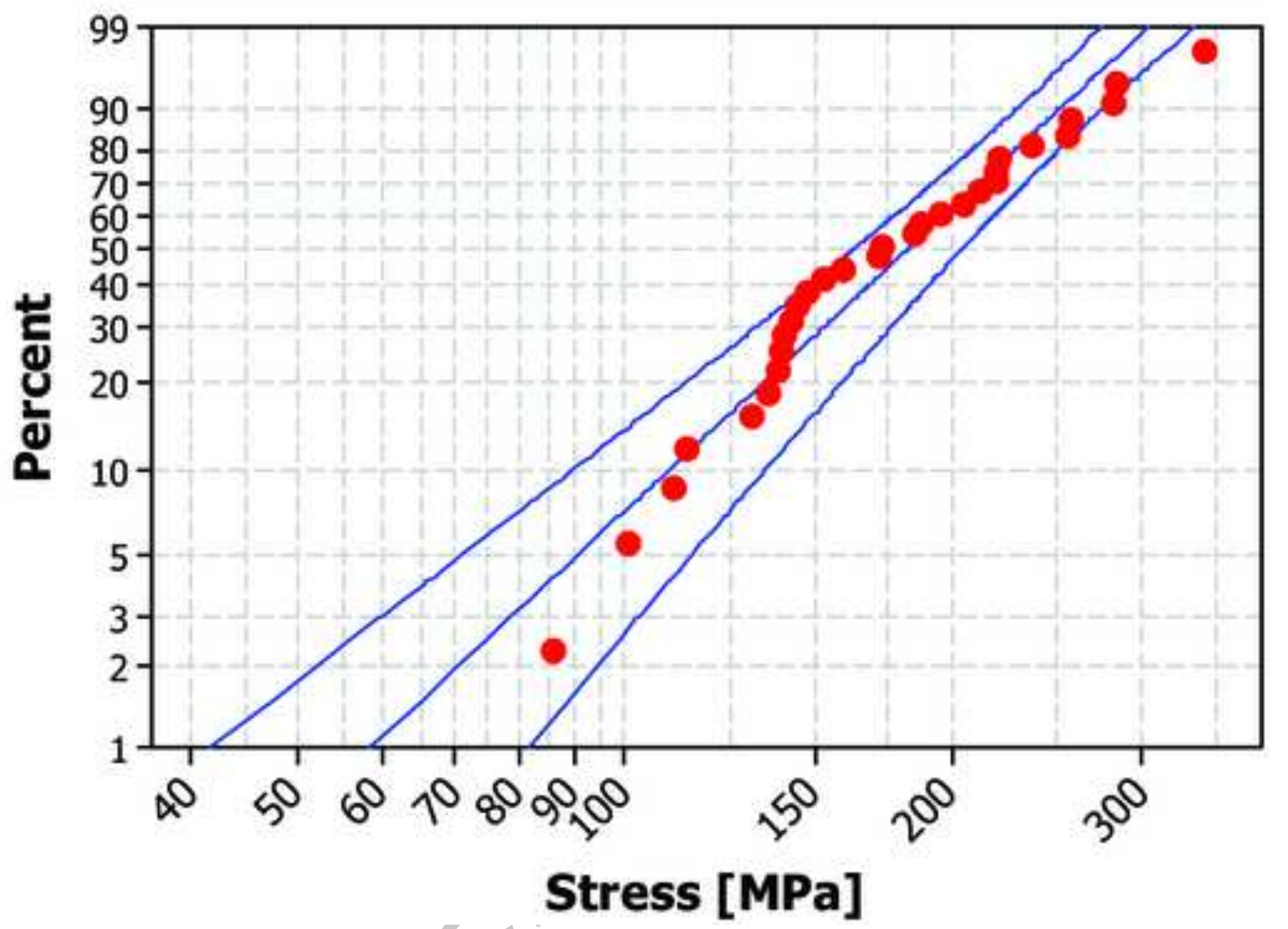

Table of Statistics Shape 3,70984 Scale Mean StDev Median IQR

Failure 201,437 181,814 54,5963 182,487 76,0017

Censor $A D^{*}$

Correlation

\section{Stress [MPa]}




\section{Probability Plot for E [MPa] \\ Weibull - 95\% CI \\ Complete Data - LSXY Estimates}

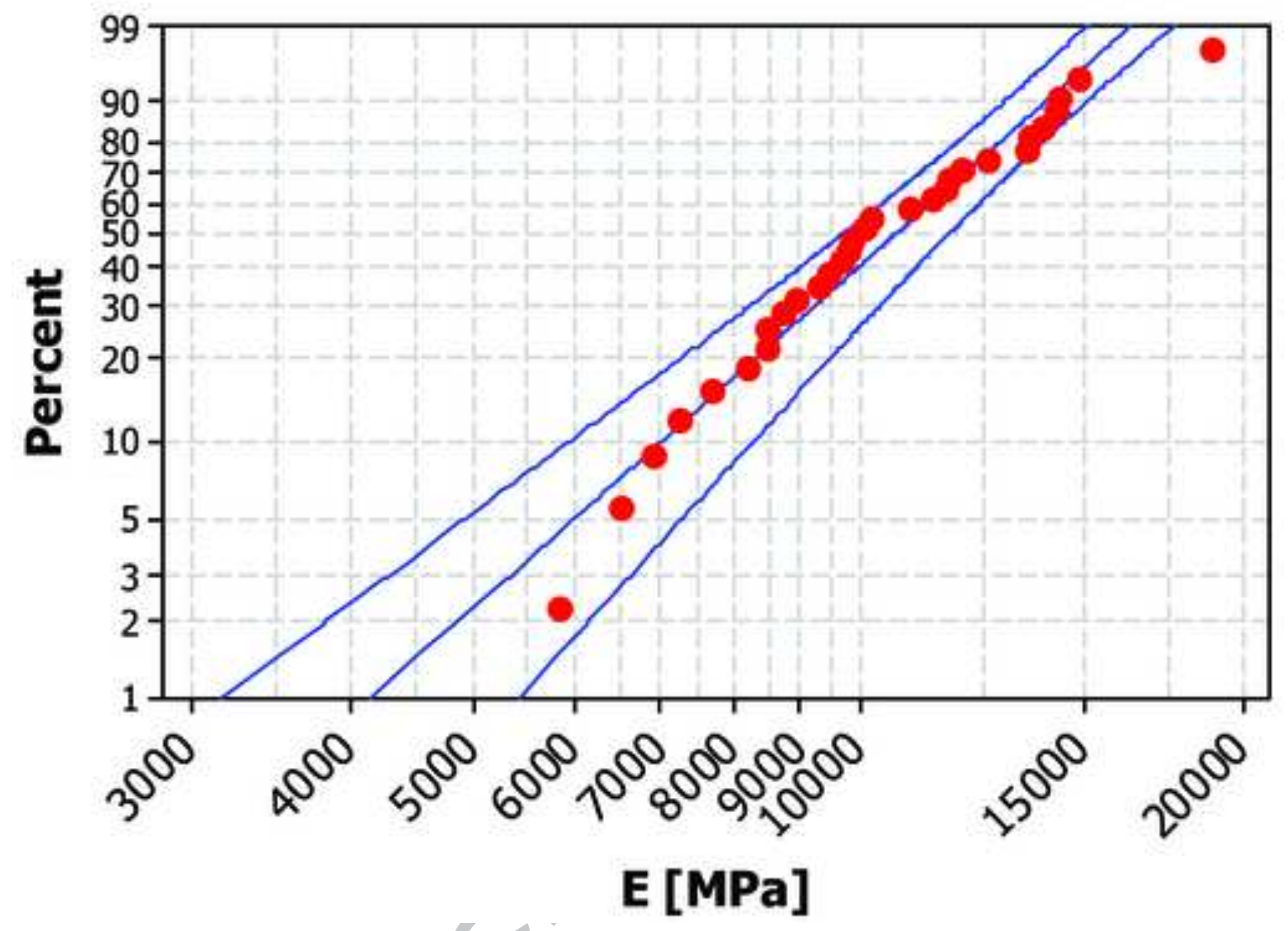

Table of Statistics Shape Scale Mean StDev Median IQR

Failure 4,46871 11624,6 10604,0 2690,61 10709,2 3709,92

Censor

AD* 1,144

Correlation 0,976 